\title{
端部筋の抜け出しを考慮した鉄筋コンクリートスラブの長期たわみ算定 CALCULATION OF LONG-TERM DEFLECTIONS OF REINFORCED CONCRETE SLABS IN CONSIDERATION OF STEEL SLIPPAGE AT FIXED EDGES
}

岩田樹美*, 李 振 宝**, 大野義照*** Tatsumi IWATA, Zhenbao LI and Yoshiteru OHNO

\begin{abstract}
Deflection of reinforced concrete slabs increase with time due to factors like creep of concrete, the decrease in the rigidity by cracking. Moreover, additional deflection after cracking is known to occur becouse of steel slippage at the fixed adge. In this paper, a method that can calculate long-term deflections of continuous reinforced concrete slabs is given. Steel slippage is evaluated by bond creep analysis in this method. A comparison of the experimental and calculated deflections shows that both are generally in agreement. The effects of slab thickness, slab effective depth, ratio of reinforcement and orther factors on the deflection of slabs are numerically analyzed.
\end{abstract}

Keywords : reinforced concrete, slab, long-term deflection, creep, shrinkage, slippage of tension steel 鉄筋コンクリート，スラブ，長期たわみ，クリープ，乾燥収縮，鉄筋の拔け出し

\section{1. まえがき}

鉄笳コンクリート 以下RC之略記 スラフれ、持続荷重下におい て曲けひひ割水による剛性低下、コンクリートのクリープ、乾燥収縮 等の影響を受け、時間の経過と共にたわみ增大する。RCスラブの 過大たわみの実態力明らかとなって以来長期たわみに関する研究力数

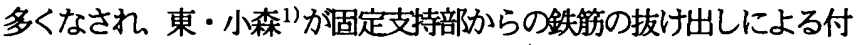
加たわみの影響を指摘し、その影響の大きいことがその後の研究によ り報告されている。

この鉄筋の拔け出しによる付加たわみを考虑した長期たわみの解析 方法についてはこれまでにいくつかの報告がなされているが、拔け出 し量をいかに定量的に算定するかが重要な問題となっている。小柳等 ${ }^{2)}$ は片引き試験体の持続载荷実験を行い、得られた実駼結果から導か れた実験式を鉄笳の抜け出し量算定式としている。この方法は初めて 鉄笳の拔け出し量を定量的に扱ったものでその意義は大きいが、鉄筋 の拔け出し量算定式がコンクリートのクリープ、乾焻叫縮および付着 クリープの関数として表現されてはおらず、それらの影響を評価する までには至っていない。また、片引き試験における実験で一かから得 られた算定式であるため、両引き試験体の抜け出しには適用できるか 检矿が必要である。岩原 ${ }^{3}$ は付着応力 $て$ すべり $\mathrm{s}$ 関係から出発しコ ンクリートのクリープ、乾梠収縮および付着クリープを考慮した鉄筋 の拔け出しを解析的に検討し、鉄筋の抜け出し問題を定式化している。 ただし、片引きモデルでは引張力がー端から鉄筋に作用し他端に等分 布反力が作用しているとし、その場合の定着長さとしてRC構造计算 規準・同解説 (以下RC規準之略記) の規定值を一律に用いている。 また、鉄笳の抜け出しを考虑した、たわみ角法による瞬時たわみの計 算式を導いているい。

*NTTファシリティース

** 耐震企画設計 工博

*** 大阪大学 教授 $\cdot$ 工博
筆者等は既報5)で、両引き試験体の持続載荷試験から得られた、 持続荷重下における $\tau-s$ 関係を用いた付着解析により、経時的な 抜け出し量が算定できることを示した。また、片持梁の載荷実験6) により、たわみを梁の曲けたわみに上記の方法で計算した鉄筋の抜 け出しによる付加たわみを加えることにより捉えることができるこ とを確認している。ここでは、付着解析においてRC引張材の両端 に異なる引張力が作用するモデルを提案している。

本研究では，付着解析により抜け出儿量を算定し、クリープ解析によ りひひ割れによる㓮性低下、コンクリートのクリープおよひ乾橾収縮を 考虑する、両端固定RCスラプの長期大わみ計算法を提案した。また 既往の央駼結果を用いてその計算去の適用性を検討すると共に、RCス ラフモテル断面についてその計算法によりたわみを計算しスラフ厚さ、 スパ等の各種要因が長期たわみおよひ鉄筋の抜け出しによる付加たわ みにおよぼす影響について検討し、それら要因の長期たわみに及ぼす影 響の定量的な洋価を試みた。

\section{2. 两端固定一方向RCスラプの長期たか夕計算阹}

たわみは、部材を材軸力向に分割しそれぞれの断面での曲率を求めモ 一ルの定理により計算する。

\section{1 付着解析による鉃笳の拔计出儿量壮算}

付着解析については昨報)で報告しているのでここではその概要のみ を示す。

付着解析モデル、図1に示すように部材両端に異なる曲けチモーメン トが作用した場合にも適用できる付着解析モデルを用いた。今回新たに 設定した解析伖定は以下の通りである。

（1）持続荷重下における $\tau-s$ 関係を図 2 に示すように完全弾望性近

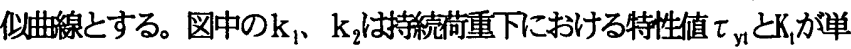




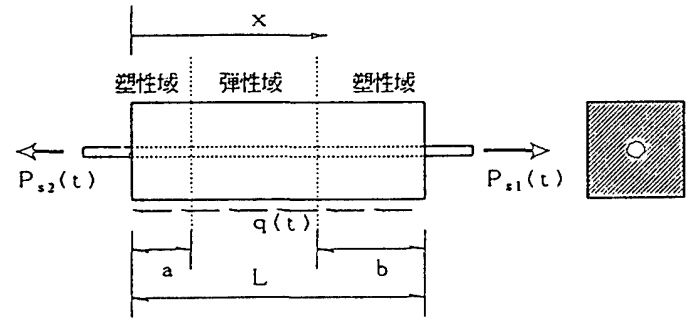

図 1 付着解析モデル

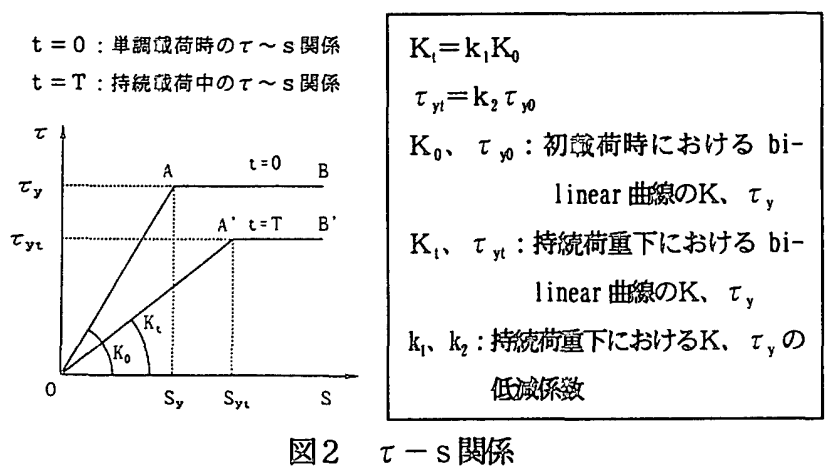

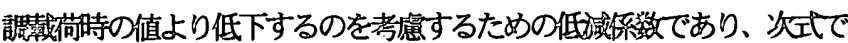
与えられるっ。

$\mathrm{k}_{1}=\left(0.25+0.5 \mathrm{t}^{\mathrm{a}}\right) / \mathrm{t}^{02}, \mathrm{k}_{2}=0.75$

この曲線で近似したモデルの特性值 $\tau_{\text {, }} \mathrm{K}_{0}$ の設定については $\tau-\mathrm{s}$

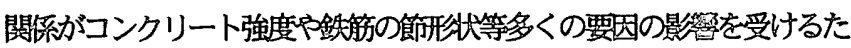

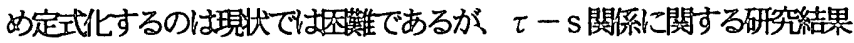

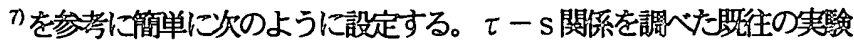

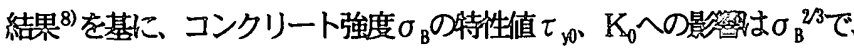

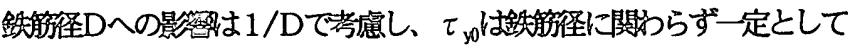
与元た。 $\sigma_{B}=240 \mathrm{~kg} / \mathrm{cm}^{2} 、 \mathrm{D} 13$ における平均值を特生值 $\tau_{y 0} ＼textrm{K}_{0}$ の基猚 值とし、この基淮值に基ついて特生值 $\tau_{w 0}, \mathrm{~K}_{0}$ を次巧て計算する。

$$
\begin{aligned}
& \mathbb{K}_{0}=11600 \times\left(\frac{\sigma_{B}}{240}\right)^{\frac{2}{3}} \times\left(\frac{13}{D}\right)\left(\mathrm{kgf} / \mathrm{cm}^{3}\right) \\
& \tau_{y 0}=34.3 \times\left(\frac{\sigma_{B}}{240}\right)^{\frac{2}{3}}\left(\mathrm{kgf} / \mathrm{cm}^{2}\right)
\end{aligned}
$$

（2）付着解析を行う際のコンクリート所面禎は、引張鉄筋とコンクリ 一トの図心之が-致するコンクリート部分が弓張力分担に対して有效で あるとし 3). 9)、図3に示すハッチ部分を解斩用コンクリート弓張有效微 面とする。

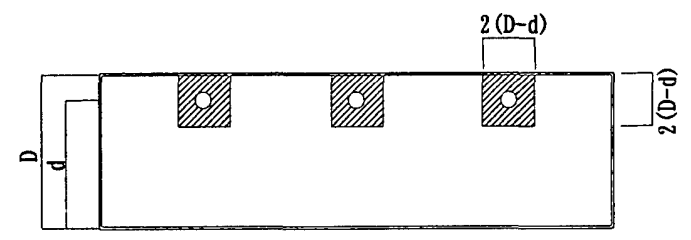

図3 解析用有効阯面

図1に示す両引き枌において時刻七における両端に作用する力をそれ ぞれ $\mathrm{P}_{\mathrm{s} 1}(\mathrm{t}) 、 \mathrm{P}_{\mathrm{s} 2}(\mathrm{t})$ 、その間に作用するせん䤠力を $\mathrm{q}(\mathrm{t})$ とすると次の 微分方程式地影学できる5)。

$$
\frac{d^{2} S_{x}(t)}{d x^{2}}=\frac{1+n^{\prime} p}{E_{s} A_{s}} \cdot U \cdot \tau_{x}(t)-\frac{q(t)}{E_{c}^{\prime} A_{c}}
$$

$$
\text { ここに, } \begin{aligned}
q(t) & =\left(\mathbb{P}_{s 1}(t)-\mathbb{P}_{s 2}(t)\right) / L, n^{\prime}=E_{s} / E_{t} \\
E_{c} & =E_{c} /(1+0.5 \phi), p=A_{s} / A_{c}
\end{aligned}
$$

$\mathrm{S}_{\mathrm{x}}(\mathrm{t})$ : 時刻 $\mathrm{t}$ の時 $\mathrm{x}$ 位置における䤪筋とコンクリートの相対すべり

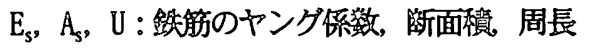

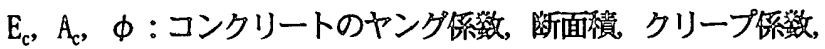

上式において仮定 (1) で示した $\tau_{\mathrm{x}}(\mathrm{t})=\mathrm{f}\left(\mathrm{s}_{\mathrm{x}}(\mathrm{t})\right)$ という $\tau-\mathrm{s}$ 䦎 係を与光れば，上式を解くことによりすべり量力訢算できる。

特列として、両引きモデルの場合 $\mathrm{P}_{\mathrm{sl}}(\mathrm{t})=\mathrm{P}_{\mathrm{s} 2}(\mathrm{t}) 、$ 片引きモデルの場 合 $\mathrm{P}_{\mathrm{s} 2}(\mathrm{t})=0$ として計算する。

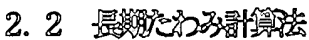

図4に長期たかみ計算のフロ 一ャートを示す。不竫定樥造 である固定支特スラプに曲げひ ひ割忆か発生すると、曲げモー メントの再配分が生じる。再配 分後の曲け゚モーメント分布を決 定する登件として左右刘称椾告 対称荷重の場合、中央部のたわ み觔0になるという回転角の 釣り合い式により、端部引張敛 筋の抜け出しによる回転角 $\theta \mathrm{s}$ を考虑して次のような条件垊が 与えられる2。

$$
\int_{0}^{1 / 2} \phi d x+\theta_{s}=0 \quad(4)
$$

ここに $\phi:$ 曲赛 1 : スパン 長期たわ外 (4) 式を满足 するようなモーメント分布に対 してモいの定理により計算す る。以下にその具体的な計算方 法を示す。

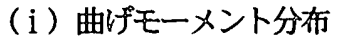
曲け゚モーメントの初期值と

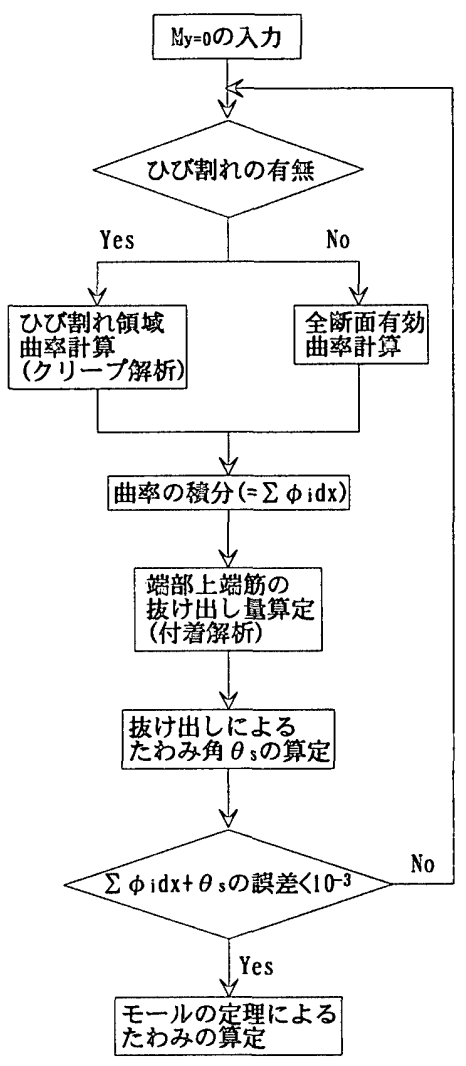

図4 フローチャート
されるモーメント分布 $\mathrm{M}_{\mathrm{y}=0}$ を与える。

(ii）ひひ割えの有無の判定

ひび割㣗による拥性低下を㘼虑するため、ひひ割れそモーメントM

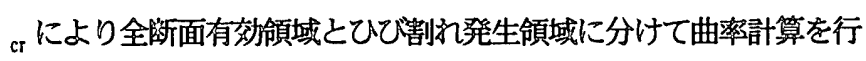
う。曲げ強度は長期的には持続応力や乾燥怄縮の影餐で見かけ上低 下する。そこで長期の曲げ強度は、クリープ限度を静的強度の7 $0 \%$ として考虑し ${ }^{10}$ 、乾燥收縮に対する鉄筋の拘束作用により生じ る引張応力 $\sigma_{\mathrm{sh}}$ を差し引いたものとした。

$$
\begin{aligned}
& \mathrm{M}_{\mathrm{cr}} \text { (瞬持) }=1.8 \sqrt{\sigma_{B}} \cdot Z \\
& \mathrm{M}_{\mathrm{cr}} \text { (長期) }=\left(1.8 \sqrt{\sigma_{B}} \times 0.7-\sigma_{s h}\right) Z
\end{aligned}
$$

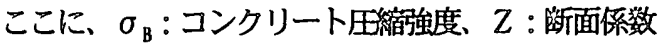

$\mathrm{M}_{\mathrm{y}}<\mathrm{M}_{\mathrm{cr}}$ のとき、Mean-Siress 法 ${ }^{11}$ によるクリープ解析で、 $\mathrm{M}_{\mathrm{y}}<$ 
$\mathrm{M}_{\mathrm{cr}}$ のとき、全断面有効として次式で曲率を計算する。

$$
\begin{aligned}
& \phi_{c r}=M_{i} / E_{t} I \\
& \phi_{s h}=0.5 E_{t} \varepsilon_{s h} b\left\langle x_{n}^{2}-\left(D-x_{n}\right)^{2}\right\} / E_{t} I \\
& \text { ここに, } E_{t} I=E_{c} /(1+\phi) \times I \text { : 全断面成性 }
\end{aligned}
$$

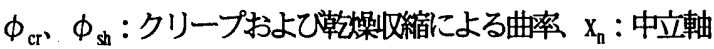

$\varepsilon_{\mathrm{sh}}:$ 乾燥収縮ひずみ $\mathrm{b}$ :断面幅 $\mathrm{D}$ : 断面せい

（iii）（ii）で求めた曲率を端部から部材中央まで積分する。

$$
\int_{0}^{1 / 2} \phi d x=\sum_{i=1}^{n / 2} \phi_{i} d x
$$

\section{ここに $\mathrm{n}:$ 分嗐数、 $\phi_{\mathrm{i}}: \mathrm{i}$ 点における曲率}

(iv) 端部引張鉄筋の拔け出し $s$ にる回転角 $\theta_{s}$ の計算

端部曲げモーメントによる端部引張鉄筋応力を断面解析により計 算し、その応力による鉄筋の拔け出し量 $\mathrm{s}$ を前述した付着解析によ り計算する。回転角 $\theta_{\mathrm{s}}$ は、 $\mathrm{s}$ を用いて次式のように表される。

$$
\theta_{s}=\frac{s}{d-x_{n}}
$$

ここに、 $\mathrm{d}$ : 有効せい、 $\mathrm{x}_{\mathrm{n}}$ : 端部ひひ割れ断面の中立軸

（v）（8）、（9）式を（4）式に代入し、（4）式が成立する まで（i ）から（iv）の繰り返し計算を行う。

(vi）たわみの計算

（4）式を満足するモーメント分布に対する中央たわみをモール の定理により次式により計算する。

$$
\delta_{l / 2}=\frac{l}{2} \sum_{i=1}^{n / 2} \phi_{i} d x-\sum_{i=1}^{n / 2} \phi_{i}\left(\frac{l}{2}-x_{i}\right) d x
$$

ここに、 $\mathrm{x}_{\mathrm{i}}$ : 固定支持端から $\mathrm{i}$ 点までの距離

\section{3. 長期ため夕計算法の適用性の蛤㣙}

\section{1 䁖往のRCスラブ実結果との比較}

過去に報告されている国内での両端固定一方向スラブの長期たわ
み実駼結果 122,13) 14，15) に対して、本報て提案した長期たわみ計算法 の適合性を検討する。併せて既往の計算法の検討も行う。

表1に検討対象としたスラブのたわみの実験值と提案した計算法 による計算值などを示す。クリープ俰数、乾燥収縮ひずみについて は報告されている実涀值を使用し、されていない場合はC E B - F I P国際指針の力法 ${ }^{16}$ により算出した。試験体S 3、S 5、S 6, S 7については施工荷重を想定した載荷初期の過荷重を作用させて いるため、過荷重による剛性低下を考虑して計算した。なお、長期 たわみ計算における端部引張鉄筋の拔け出し量の計算は、試験体の 支持状況を考虑して片引きモデルとして計算を行った。

瞬赫たわみについては、S 1-Bの計算值がかなり小さくなって いる。そこで載荷開始材令が 56 日之遅いため乾燥収縮によるひび

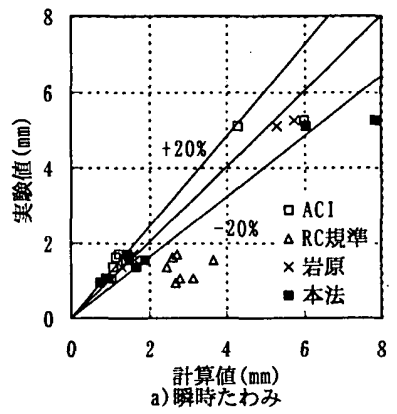

\begin{tabular}{|c|c|c|c|c|c|c|c|c|c|c|c|c|c|c|c|c|c|c|c|c|}
\hline \multirow{3}{*}{ 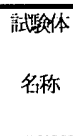 } & \multirow{3}{*}{$\begin{array}{l}\text { 断面对 } \\
B \times D(\mathrm{~cm})\end{array}$} & \multirow{3}{*}{$\begin{array}{l}\text { スパ } \\
\text { ン } \\
(\mathrm{cm})\end{array}$} & \multirow{3}{*}{$\begin{array}{l}\text { かぶり } \\
(\mathrm{cm}) \\
\text { 上端 } \\
\text { 下端 }\end{array}$} & \multicolumn{2}{|c|}{ 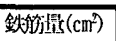 } & \multirow{3}{*}{$\begin{array}{l}\text { クリー- } \\
\text { プ倸数 }\end{array}$} & \multirow{3}{*}{$\begin{array}{c}\text { 収緔ひ } \\
\text { ずみ } \\
\left(\times 10^{-5}\right)\end{array}$} & \multirow{3}{*}{$\begin{array}{c}\text { 䕎重 } \\
w \\
(1 \mathrm{w} / \mathrm{m})\end{array}$} & \multicolumn{2}{|c|}{ コンクリート } & \multirow{3}{*}{$\begin{array}{l}\text { 加力 } \\
\text { 材哺命 } \\
\text { (日) }\end{array}$} & \multicolumn{5}{|c|}{ 榎赫たわみ(n) } & \multicolumn{4}{|c|}{ 長期たわみ(m) } \\
\hline & & & & \multirow{2}{*}{ 端部 } & \multirow{2}{*}{\begin{tabular}{|c|} 
中块 \\
部
\end{tabular}} & & & & \multirow{2}{*}{ 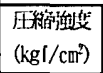 } & \multirow{2}{*}{$\begin{array}{c}\text { 弾性缧数 } \\
\left(10^{3} \mathrm{kgl} / \mathrm{cm}^{2}\right)\end{array}$} & & \multirow[t]{2}{*}{ 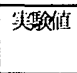 } & \multicolumn{4}{|c|}{ 計算值 } & \multirow[t]{2}{*}{ 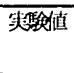 } & \multicolumn{3}{|c|}{ 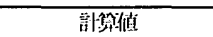 } \\
\hline & & & & & & & & & & & & & $\mathrm{ACI}$ & 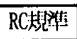 & 岩原还 & 本法 & & $\mathrm{ACl}$ & RC㚘售 & 树法 \\
\hline $\begin{array}{c}\text { 松崘 } \\
A-1\end{array}$ & $100 \times 12$ & \multirow[b]{2}{*}{380} & \multirow{2}{*}{$\begin{array}{l}2.5 \\
2.5\end{array}$} & \multirow{2}{*}{$\begin{array}{l}\text { 4. } 99 \\
\text { 3. } 57\end{array}$} & \multirow{2}{*}{$\begin{array}{c}0 \\
3.57\end{array}$} & \multirow[b]{2}{*}{3.72} & \multirow[b]{2}{*}{500} & 0.567 & \multirow[b]{2}{*}{168} & \multirow[b]{2}{*}{ 1. 85} & \multirow[b]{2}{*}{30} & 1.53 & 1.41 & 3. 67 & 1.63 & 1. 91 & 16 & 3. 37 & 10.6 & 17.3 \\
\hline $\begin{array}{l}\text { 松峆 } \\
A-2\end{array}$ & $100 \times 12$ & & & & & & & 0.486 & & & & 1.04 & 1.04 & 3. 15 & - & 0.91 & 11.6 & 2.50 & 9.05 & 13.3 \\
\hline $\begin{array}{l}\text { 硙场 } \\
\text { SI-1 }\end{array}$ & $45 \times 13.7$ & \multirow{3}{*}{360} & $\begin{array}{l}3.7 \\
3.2\end{array}$ & \multirow{3}{*}{$\begin{array}{l}2.14 \\
\text { 2. } 14\end{array}$} & \multirow{3}{*}{$\begin{array}{c}0 \\
2.14\end{array}$} & 4. 45 & 503 & 0.43 & & & & 1. 36 & 1.09 & 2. 48 & 1. 32 & 1.7 & 17.4 & 2. 94 & 7. 78 & 15.7 \\
\hline $\begin{array}{l}\text { 岩憬 } \\
\text { SI-3 }\end{array}$ & $45 \times 13.5$ & & $\begin{array}{l}1.5 \\
3.2\end{array}$ & & & & & 0.429 & 204 & 2. 32 & 30 & 1.63 & 1. 15 & 2. 61 & 1. 33 & 1.5 & 15.7 & 3. 10 & \& 41 & 14. 5 \\
\hline 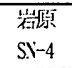 & $45 \times 13.3$ & & \begin{tabular}{|l|}
5.3 \\
3.2
\end{tabular} & & & 4. 6 & 520 & 0.427 & & & & 1.71 & 1. 24 & 2. 74 & 1.62 & 1.45 & 17.8 & 3.35 & 8. 87 & 25.4 \\
\hline $\begin{array}{l}\text { U1LA } \\
\text { S3 }\end{array}$ & & & & 1.43 & 0 & 3. 14 & 317 & 0. 2304 & & & 3 & 1. 06 & 0.95 & 281 & - & 0.96 & 5. 46 & 1.99 & 6. 95 & 5. 24 \\
\hline $\begin{array}{l}\text { W1 } \\
\text { S5 }\end{array}$ & $40 \times 12$ & 360 & 2. 5 & 1.43 & 1.43 & 1. 68 & 272 & 0.1728 & 150(7日) & 2. 21 (7日) & 28 & 0.96 & 0.75 & 2. 68 & - & 0.73 & 3. 92 & 1. 58 & 5. 32 & 3.1 \\
\hline $\begin{array}{l}\text { ILA } \\
56\end{array}$ & & & 2. 5 & 2. 54 & 0 & 3. 11 & 232 & 0.2496 & 221 (28日) & 2. 32 (28日) & 3 & 5. 24 & 6.01 & 11.4 & 5. 77 & 7.85 & 19.62 & 12.6 & 19.3 & 17.4 \\
\hline $\begin{array}{l}\text { W.ith } \\
\text { St }\end{array}$ & $40 \times 13$ & 500 & & 2. 54 & 2. 54 & 1. 67 & 199 & 0.1872 & & & 28 & 5.08 & 4. 30 & 10.8 & 5. 31 & 6.05 & 14. 78 & 9.03 & 15.6 & 13.1 \\
\hline $\begin{array}{l}\text { 小森 } \\
\text { SI-B }\end{array}$ & $25 \times 10$ & 500 & $\begin{array}{l}3 \\
3\end{array}$ & $\begin{array}{c}0.57 \\
0\end{array}$ & $\begin{array}{c}0 \\
0.57\end{array}$ & 2 & 345 & 0.06 & 205 & 1. 62 & 56 & 13 & 5. 99 & 15.7 & - & $\begin{array}{c}5.6 \\
(14.6)\end{array}$ & 46 & 12.0 & 34.6 & 50.2 \\
\hline
\end{tabular}
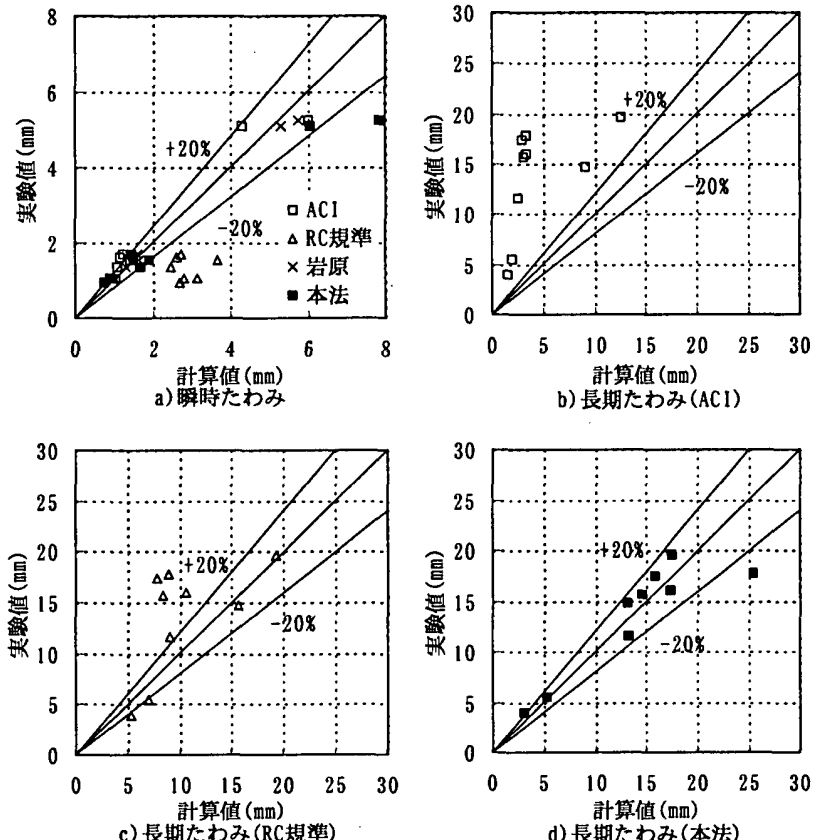

図 5 たわみの計算値と実験值との比較

表 1 既往の両端固定R Cスラブ試験体とそのたわみ（実測值と計算値の比較） 
割行耐力の低下が生じていると侾え、長期のひひ割耐力を用いて 計算したところ $14.6 \mathrm{~mm}$ と実験做にほぼ等しくなった。このS 1 Bの計算結果からも分かるように瞪時たわみについてはひひ割れ発 生による畔性低下のたわみに及活す影智が大きいと言える。

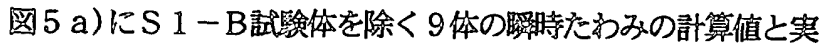

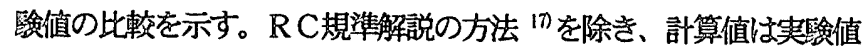
を良く织えている。ただしACI の計算法 ${ }^{18}$ は、端部筋の报け出し

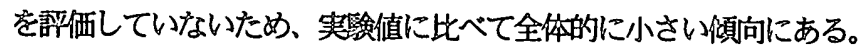
$\mathrm{RC}$ 規㴖についてはひひ割れによる倍率 $\mathrm{K}_{1}$ を長期と同じ值で評価

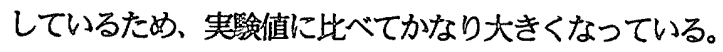

図 5b)〜d)にS 1-B試踚体を除く長期たわみの計算值之実踰值 の比較を示す。ACI の計算法は文献 17)にも述べられているよう にかなり過小評価する結果となっている。 RC規準についても端部 筋の抜け出しの影響を評価していないので、実跧值に比へて全住的 に小さくなっている。本法による計算值は実䟻值を良く近似してお り年法の適合性を確梕できた。

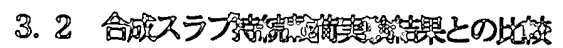

等者らが行ったプレストレスト鉄筋コンクリート合成スラプの持

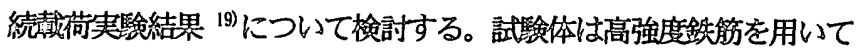
プレストレスを導入したプレキャスト板に後打ちコンクリートを打 設した合成床板であるため、以下のような計算方法を用いた。

（1）長期たわみ計算法の合成スラプに対する適用

敦燥坆縮以外の要因による增大たわみについては，一体打ちの場 合と同樣に計算する。ただし、プレキャスト部にはプレストレスが 作用しているため、下緑が引張となるような曲け゚モーメントが生ず る場合についてはひひ割れモーメントにプレストレスの影響を若虑 した。

ヤング係效およびクリープ係變はプレキャスト部之後打ち部の面

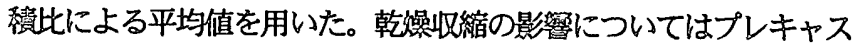
卜部之後打ち部の收縮差による增大曲率を坂、六車の提案式 ${ }^{200}$ を用

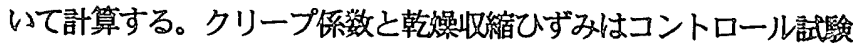
体の測定結果から得られた回帰式を使用し、プレキャスト部の朝方 向收縮についてはプレストレスによるクリープひずみを考虑した。

(2) 実跲概要

図6に試験体の形状および寸法を示す。試䟻体はコンクリート製 戴待フレームで支えられた両端固定一方向スラプで、スパンは内法 寸法で $450 \mathrm{~cm}$ 、スラフ断面形状はプレキャスト部が中央部：100 $\times 10 \mathrm{~cm}$ 、両端部 : $100 \times 7 \mathrm{~cm}$ の山形スラプで、これに後打ちコ

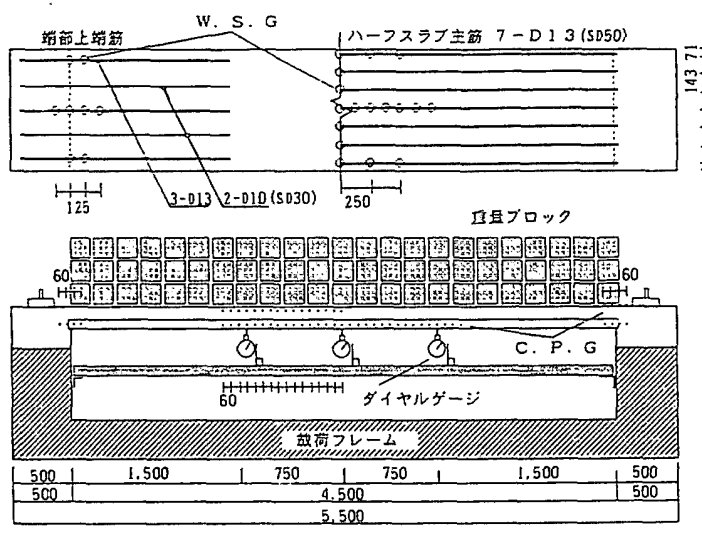

図6 試験体の形状、寸法
ンクリートを打設し全せいを $15 \mathrm{~cm}$ とした。䒾荷は後打ちコンクリ 一ト打設後 40 日目 (先打ちコンクリートでは材令 63 日目に䞑応) に䒠施した。娃続载荷何重は $530 \mathrm{kgf} / \mathrm{m}^{2}$ である。プレキャスト部秥 よび後打ら部のコンクリートにはそれぞれ呼び強度 $270 \mathrm{kgl} / \mathrm{cm}^{2}$ 、 $210 \mathrm{kgl} / \mathrm{cm}^{2}$ 、スランプ $18 \mathrm{~cm}$ のレディミクストコンクリートを用い た。ハーフスラブ主筋には高強度異形銑筋SD490 のD13 を、合成 スラプ端部上端筋にはS D 295 のD13 とD10 を併用した。舁柃の詳 細については文献 19）を参照されたい。

(3) 等踰結果との比較

図7に中央たわみの経時変化を示す。たわみの計算值は、淕荷後 のひひ割れモーメントの計算において曲げ強度を瞬時の曲げ強度の $70 \%$ として計算しており、㽤性を過小俨価するため戴荷初期におい

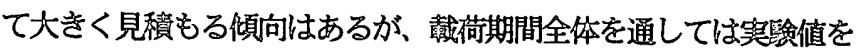

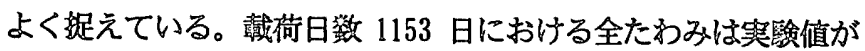
$11.2 \mathrm{~mm}$ 、計算値が $10.6 \mathrm{~mm}$ で両者の比率（実駼值/計算値）は 1.06 である。図7 中に瞹時、クリープ、端部引張鋯筋の掋け出しお よびコンクリートの乾燥区縮差によるたわみの增大（計算值）を示 している。抜け出しによる付加たかみ $\delta_{s}$ は（9）式より得られる $\theta_{s}$ を用いて次式で計算した。

$$
\delta_{s}=\frac{\theta_{s} l}{4}
$$

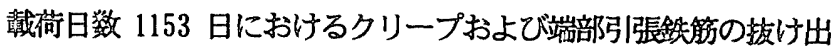
しによる增大たわみがそれぞれ全体の $45 \%$ ４2\%を示しており、そ れらの全体に占める割合が大きい事が分かる。双縮差による增大た かみが小さいが、試鍳体の罒縮差自仵が小さいことと、プレストレ スによりひび割彴端部以外に生じていないことによるものと考え られる。また、收縮差による增大たかみか時間の絽過とともに小さ くなっているが、これはプレキャスト部におけるプレストレスによ るクリープひずみにより叹縮差が娍少するためである。

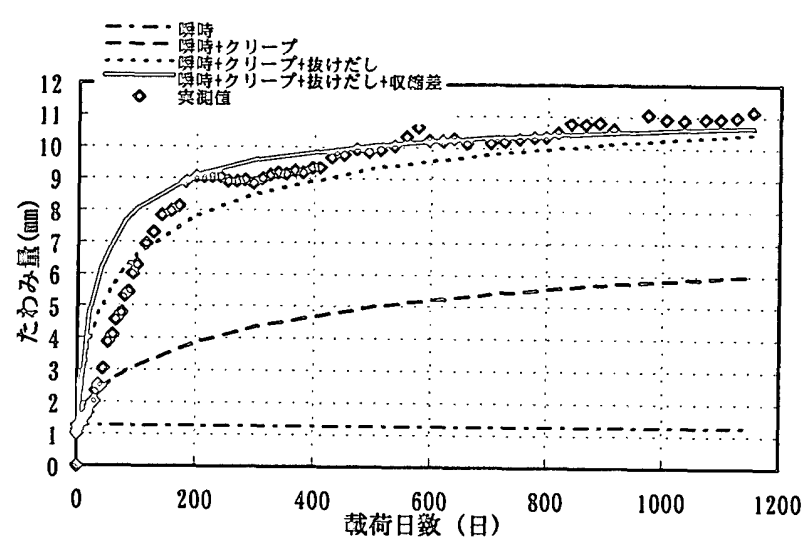

図7 中央たわみの経持変化

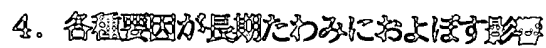

本馀文で提案した長期たかみ計算法を用いて、スラプ厚さ、スパ

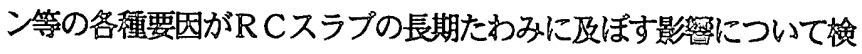
討する。

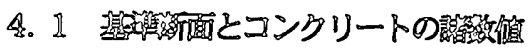

図8に基準听面の形狱および寸法を示す。断面諸元は以下の通り である。 


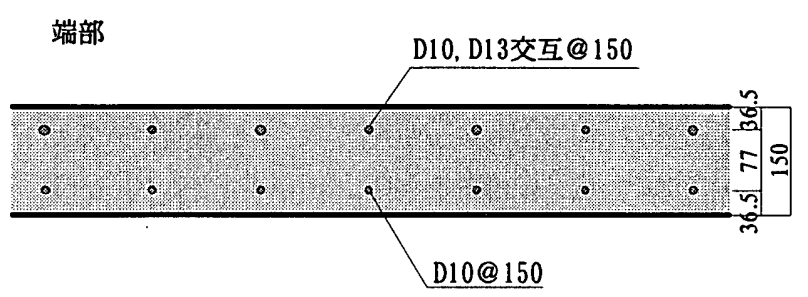

中央部

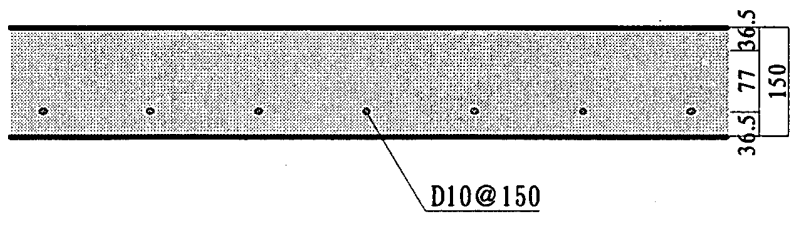

図8 基準断面

コンクリート強度 : 実強度を $240 \mathrm{kgf} / \mathrm{cm}^{2}$ とする。

スラブ厚さ : $15 \mathrm{~cm}$ 、スパン : $4.5 \mathrm{~m}$ 、かぶり厚さ : $3 \mathrm{~cm}$ 仕上け荷重十積載荷重 : $340 \mathrm{kgf} / \mathrm{m}^{2}$

クリープ係数、乾嬠収縮ひずみ :

クリープ係数 $\varphi$ ，と乾燥収縮ひずみS,の関係を、プレストレストコ ンクリート設計・施工規準・同解説21)に示されている関係式を用い て決定した。

$$
\begin{aligned}
& S_{t}=S_{n} \frac{\varphi_{t}}{\varphi_{n}} \\
& \varphi_{t}=\frac{a b_{1} t}{10.5+0.25 t} \\
& S_{n}=5 \times 10^{-4} a b_{2}
\end{aligned}
$$

ここに、 $\mathrm{S}_{\mathrm{n}}$ : 乾嬠収縮ひずみ最終值、 $\varphi_{n}$ :クリープ係数最終值

a : 部材断面寸法の大小による影響を表す定数

$\mathrm{b}_{1}, \mathrm{~b}_{2}$ : コンクリートの乾湿の影響を表す定数

$\mathrm{t}$ : 材令(日)

（12）式に（13）、（14）式を代入

$$
S_{t}=5 \times 10^{-4} a b_{2} \times \frac{0.25}{a b_{1}} \times \varphi_{t}
$$

$\mathrm{b}_{1}=\mathrm{b}_{2}$ とすれば乾嬠収縮ひずみとクリープ係数の関係は次のよ うになる。

$$
S_{t}=1.25 \times 10^{-4} \varphi_{t}
$$

クリープ係数、乾燥収縮ひずみはR C 規準で示されている值を参 考に、（16）式の関係からそれぞれ $\varphi_{n}=3.2 、 \mathrm{~S}_{\mathrm{n}}=4 \times 10^{-4}$ と設定し た。

\section{2 計算を行ったケース}

表 2 に示すように $8 つ の$ 要因の長期たわみへの影響を調べた。 Hシリーズはスラブ厚さのみを $12 \mathrm{~cm}$ mら $21 \mathrm{c} \mathrm{m}$ まで変化させ、 H12 等と表示している。Dシリーズは施工精度としての端部上端 筋の下がりによりスラブ端部の有効せいが低下したときの長期た わみへの影響を調べるため、有効せいの設計值に対する実有効せ いの比を有効せい比として $0.5 \sim 1$ まで変化させている。Lシリ
一ズはスパンを $3 \mathrm{~m}$ から $5.5 \mathrm{~m}$ まで変化させている。P Tシリー ズは引張鉄筋の間隔および径を変えて、端部引張鉄筋比を $0.31 \%$ から $1.12 \%$ まで変化させている。複筋比は端部で 0.69、中央部 で0であり一定としている。Wシリーズは積載荷重を $100 \mathrm{kgf} / \mathrm{cm}^{2}$ から $500 \mathrm{kgf} / \mathrm{cm}^{2}$ まで変化させている。Sシリーズは乾嬠収縮ひず みを $2 \times 10^{-4}$ から $6 \times 10^{-4}$ まで変化させている。クリープ係数は （16）式で示した関係にしたがって設定している。TおよびKシリ 一ス推定か泪難である付着強度 $\tau_{\mathrm{y} 0}$ および付着用性 $\mathrm{K}_{0}$ が長期たわ みに及ほす影響を調べるため、 $\tau_{y 0}$ を $20 \mathrm{kgf} / \mathrm{cm}^{2}$ から $60 \mathrm{kgf} / \mathrm{cm}^{2} 、 \mathrm{~K}$ ${ }_{0}$ は $2000 \mathrm{kgf} / \mathrm{cm}^{3}$ から $18000 \mathrm{kgf} / \mathrm{cm}^{3}$ まで変化させている。ケースに

\begin{tabular}{|c|c|c|}
\hline シリーズ & 要因 & 水淮 \\
\hline $\mathrm{H}$ & スラフ厚さ $(\mathrm{cm})$ & $12,15,18,21$ \\
\hline $\mathrm{D}$ & 有效せい比 & $0.5,0.6,0.7,0.8,0.9$, 目 \\
\hline $\mathrm{L}$ & スパン(m) & $3,3.5,4,4.5,5,5.5$ \\
\hline PT & 端部上端筋比(\%) & $\begin{array}{lllllll}0.31, & 0.41, & 0.56, & 0.64, & 0.78, & 0.87, & 1.12\end{array}$ \\
\hline $\mathrm{w}$ & 程载荷重 $(\mathrm{kg} / \mathrm{m})$ & $100,200.300,400,500$ \\
\hline$S$ & $\begin{array}{c}\text { 収䑿ひずみ }\left(\times 10^{-1}\right) \\
(\text { クリープ俰数 })\end{array}$ & $2(1.6), 3(2.4), 4(3.2), 5(4), 6(4.8)$ \\
\hline $\mathrm{K}$ & 付着济性 $\left(\mathrm{kg} / \mathrm{cm}^{3}\right)$ & $2000,4000,6000,10000,13100,18000$, \\
\hline.$T$ & 付着強度 $\left(\mathrm{kg} / \mathrm{cm}^{2}\right)$ & $20,30,34.3,40,50,60$ \\
\hline
\end{tabular}
よっては計算上固定支持端部にひひ割れの生じないこともあるが、 本検討においてはすべてひひ割れが生じ鉄筋の抜け出しがあるもの として計算する。

表 2 要因と水準

口の数值は基洀値を表す

\section{3 計算結果およひ察}

（1）固定支持部のモデル化の相違がたわみに及ぼす影響

固定支持部からの鉄筋の抜け出し量を付着解析により計算する 場合、対象とする接合部に応じて両引きモデルあるいは片引きモ デにモデル化して計算する。図 9 は図 1 に示す付着解析モデル において鉄筋径D13、かぶり厚さ $3 \mathrm{~cm}$ 严して片引きおよび両引 きにモデ化したときの鉄筋応力と端部すべり量との関係の解析 值を示したものである。同図よりすべり量は定着長さにより決ま るため、鉄筋応力が大きくなれば実部材では梁幅に対応する解析 試験体長さの長いものほどすべり量は大きくなっている。片引き モデルの場合、鉄筋とコンクリート間の付着力と荷重との釣り合 いから決定される定着長さによりすべり量が決まり、両引きモデ ルとの大小関係はこの定着長さの大小関係で决まる。本解析では 片引きモデルより求めた端部すべり量は両引きモデルの $30 \mathrm{~cm}$ と $40 \mathrm{~cm}$ の中間にある。しかし、鉄筋応力が $2000 \mathrm{kgf} / \mathrm{cm}^{2}$ までの 範囲では片引きモテルと両引きモデルに大きな差異はなく、瞬時 についてはモテル化の相違による影掣はほとんどないと言える。 同様の付着解析モデルに対して鉄筋応力を $2000 \mathrm{kgf} / \mathrm{cm}^{2}$ で持続載 荷した場合の端部すべり量と乾燥収縮との関係を図 10 に示す。 長期のすべり量にはモテル化の相違および両引きにおいては試験 体長さの影響が見られ、特に試験体長さの小さいときにすべり量 が小さくなっている。このすべり量の相違が長期たわみにおよぼ す影響を調べるため、Hシリーズ、PTシリーズおよびSシリー ズについて長期たわみの両引きモテルによる計算値の片引きモデ 
ルによる計算值に対する割合と端部引張錐筋応力との閣係を図 11 に示す。同図より鍇筋応力が大きく試驗体長さの大きい両引き天 デルが片引きモデルの 1.2 倍程度と大きくなることがあるが、鉃 筋応力が $2000 \mathrm{kgl} / \mathrm{cm}^{2}$ までは 0.8〜1の箇围に搉まり、片引きモ デルで計算すれば両引きモデルも含めて安全側に缠価できること が分かる。以下の考察でけ端部引張鉄筋の抜け出しを片引きそデ ルにモデル化して解析した結界を用いる。
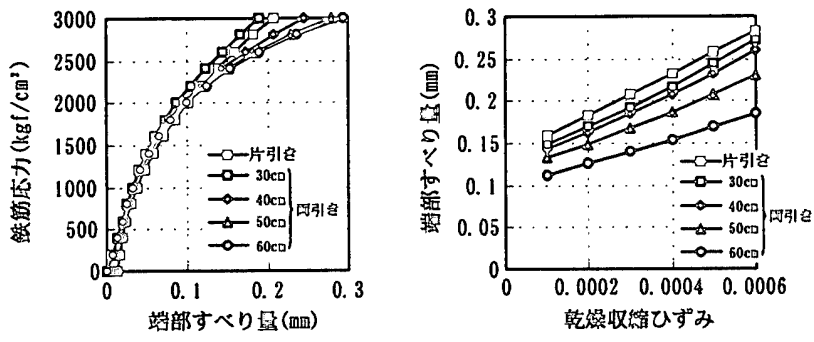

図 9 鉃筋応力ー端部すべり関係 図10 すべり量ー sh関係
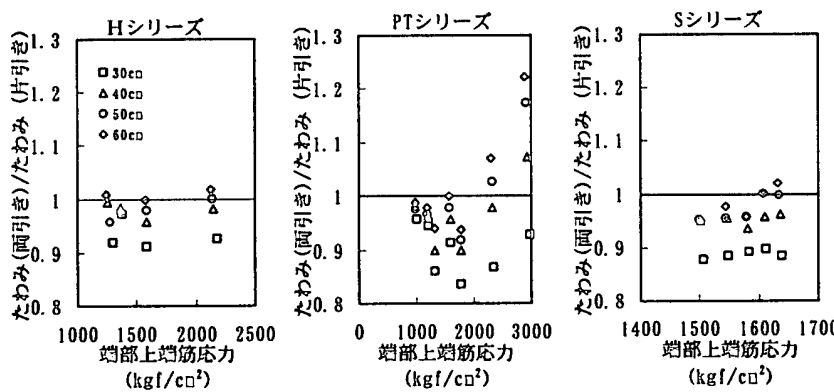

図11 長期たわみの両引きモデルによる計算値の片引きモデルによ る計算值に凉する割合

（2）端部モ一メントおよび端部引張鉄筋応力

図 12(a)、(b)に端部モ一メントおよび端部引張鉄筋応力と各種要

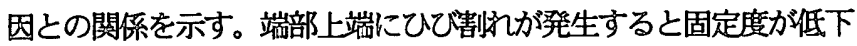
し、端部モ一メントは減少する。娃続荷重を受けてスラブ部分の㓯 珄が低下すると、応力再配分により端部モーメントは明时に比べて 增大する。さらにクリープの影響で中立韩が下がるため、同一モ一 メントに対する銑笳応力は大きくなる。これら二つの影变で長期の 銑筋底力は暖時より大きくなり、抜け出し量增大の原园となってい る。長期の端部モ一メント低下率（完全端部固定支持として計算さ れる端部モーメントに対する割合）は $0.85 〜 0.95$ の範围にある。

（3）端部引張鉄筋拻け出し量およびたわみ

図12(c)、（d)、（e）に端部引張鉃筋抜け出し量、披け出しによる 付加たわみおよび全たわみと各種要因との関係を示す。全体的に端 部筋すべり量、付加たわみおよび全たわみと各要因との䦥係は同じ 傾向を示している。スラプ厚さ、スパン、銑筋比のたわみに及ぼす 影繁は大きい。スラプ厚さについては、スラプ厚さの小さいものほ

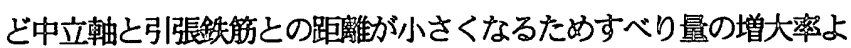
り付加たわみの增大率が大きくなっている。施工時の不具合として 侾えられる有勃せいの低下によるたわみは非常に大きく、本解析で は文献 2)に示されている端部有勃せい比の逆攻以上にたわみは大

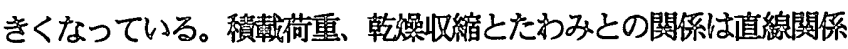

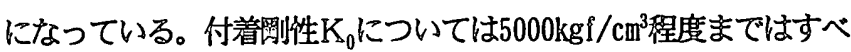
り量にその影繁が見られるが、たわみにはその影皦はほとんど見ら
れない。それに比べ同じ付着特珄值である ${ }_{50}$ のたわみに対する影 得は大きく、 $\tau_{\mathrm{y} 0}$ の玼少とともにたわみは观曲線的に增加しており、

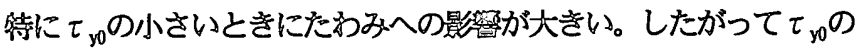
推定についてはある程度の辡度が必要である。

図 13 に長期たわみの弾性たわみに対する倍鳘を示す。端部鉃筋 応力が大告くなる程倍率 も大きくなっている。端

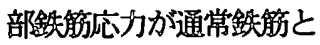
して使用される SD295 の 長期許容応力度 $2000 \mathrm{kgl} / \mathrm{cm}^{2}$ 以下でも、 倍率が 6〜15 になる。 過去の突飸結界から、長 期たわみは弾性たわみの 12〜18 倍になると報告 されている 22が、図 13 によれぱそのような倍率 においては端部筋応力が $2000 \mathrm{gf} / \mathrm{cm}^{2}$ を超えると考 えられる。

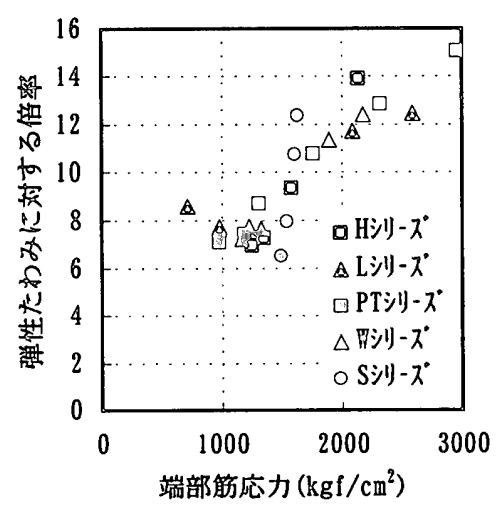

（4）端部引張銑筋の抜け出しによる付加たわみの全たわみに占め る割合

端部引張銑筋の抜け出しによる付加たわみの全たわみに占める割 合と各要因との関係を図 14 に示す。付加たわみの割合は䁔時の方 が大きく瞬㭙は 0.4 前後、長期は 0.3 前後を示しており持続载倚に よるたわみの增大率は付加たわみよりも曲げたわみの方が大きいこ とを示している。またそれぞれの要团については、全たわみの小さ いものすなわちスラプ部分の凨性の大きいものほど付加たわみの割 合は大きくなっている。
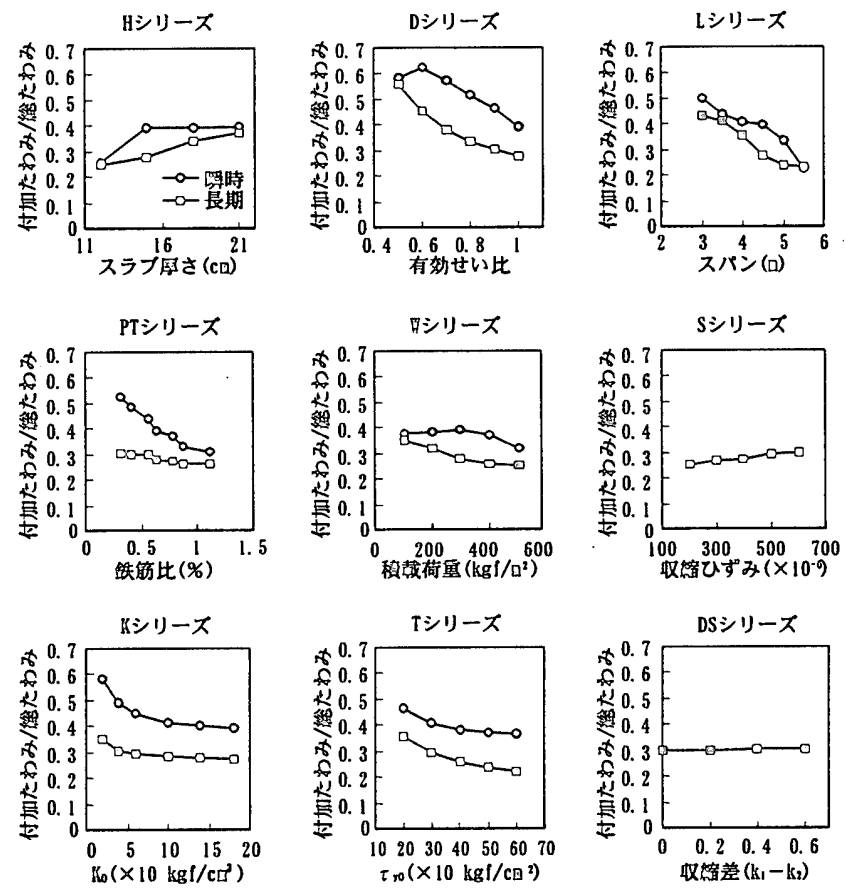

図14付加たわみの全たわみに対する割合 

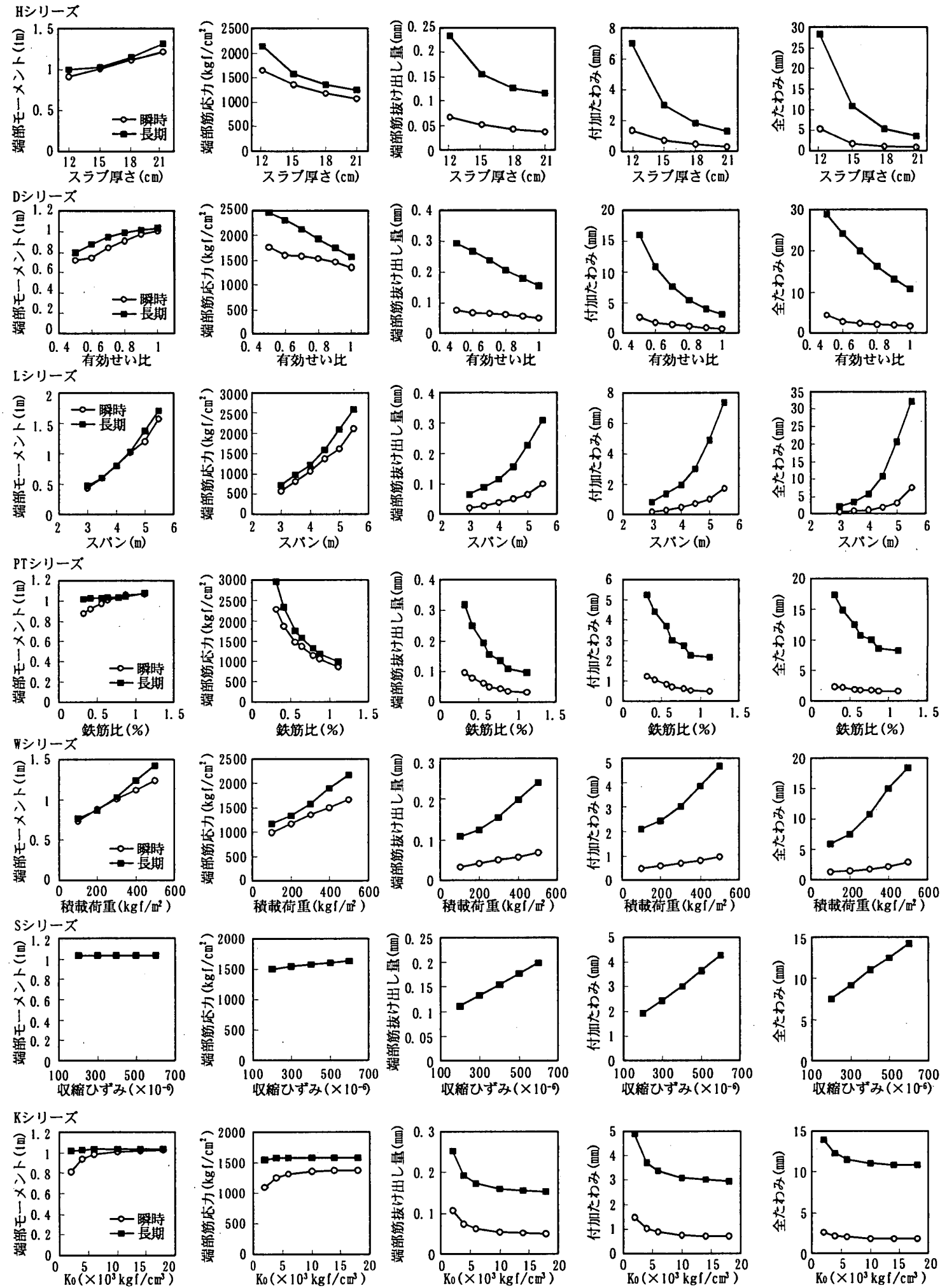

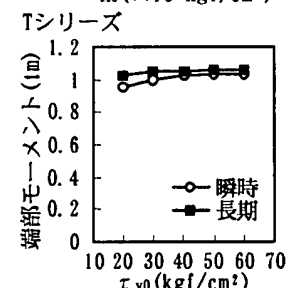

(a)

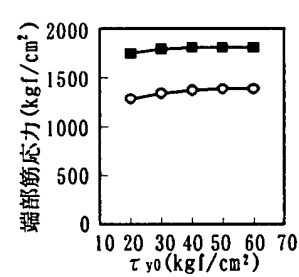

(b)

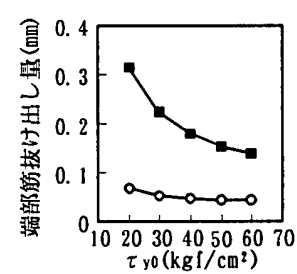

(c)

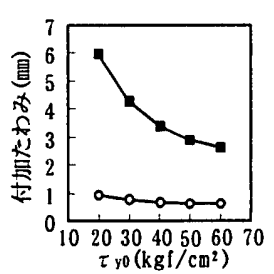

(d)

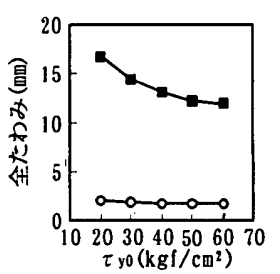

(e)

図 12 （a）端部モーメント、(b) 端部筋応力、(c) 端部抜け出し量、(d) 付加たわみ、(e) 全たわみ 
5. 紊灾的

以上の检討より得られた主な結果をまとめると以下のとおりであ る。

（1）持続何重下において両端固定RCスラプは、ひひ嘒けによる

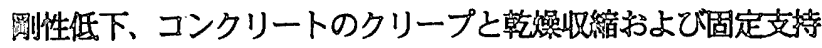
部からの銑筇の拢け出しにより增大するが、これらの影響を考 急した長期たわみ計算法を䛪導した。

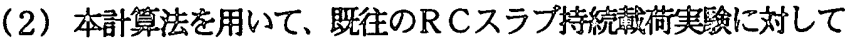
梠証した結果、長期たかみの実湘值をよく织えておりその適合 性を確認した。また、持続载荷実験が行われた P R C 合成スラ ブのたわみについて計算した結果、コンクリートのクリープお よび端部筋の抜け出しによる増大たわみはそれぞれ長期たわみ の45、42\%を占め、それらの全たわみに占的る割合が大きい。

(3) 本計算法を用いて一般的なRCスラプにおけるスラプ厚さ、ス

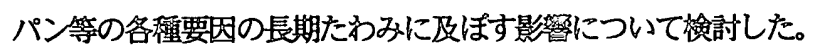
その結累、長期たわみ弾徃たかみの6〜15 倍となり、また端 部筋の拻け出しによる付加たわみの全たわみに占める割合は大 略瞅時で 40\%、長期で 30\%で、端部筋の拔け出しによる付加た わみの影贸の大きいことを定量的に捉えることができた。

今後、本計算法を簡略化した鉄筋コンクリートおよびプレストレ スト鉄筋コンクリート曲げ材の長期たわみの略算法について裣討し ていく予定である。

\section{渗考文献】}

1)東 洋一、小落清司 : 銑筋コンクリート帯スラプの長期たわみに

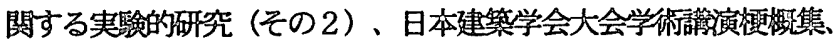
棈造系 II - II、pp.1837-1838、1977.10

2)武田筹一、高福久雄、小柳光生 : 床スラプの長期たわみに関する 研究、コンクリート工学論文、Vol.21、pp.115-12A 1983.9

3)岩原照次 : 長期設計荷重下における R C 造スラプの鉄矢の抜け出 しに閣する解析的研究、日本建学会满造系諭文焦、第 400 号、 pp.45-57、1989.6

4) 岩原照次: 使用荷重下における銑筋コンクリート床スラプの長期 曲り問題に対する解析法に関する研究（第一報 ひひ割㣗を生じた 一方向スラプの瞹時曲け問題に対する解析法)、日本建筑学会幥造 系詥文焦 第415 号、pp.63-73、1990.9

5)大野義照、李 振宝、軨木計夫：持続荷重下における異形銑筋之 コンクリート間の付着応力ーすべり関係、日本䞳築学会幥造系諭文 焦 第459号、pp.111-120、1994.5

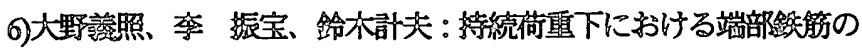

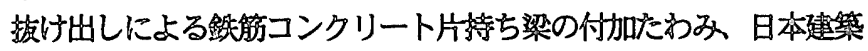
学会傤造系諭文第 第467号、pp.111-120、1995.1

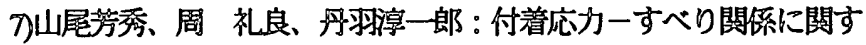
る实匬的研究、土木学会諭文鉎告焦、第 3A3 号、pp219-228、 19843

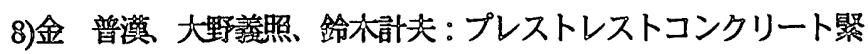

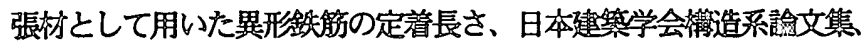
第472号、pp.121-128、1995.6

9)六車 熙、孚田司郎、富田幸次郎：鋼とコンクリートの付着に関 する基磁的研究（I 付着応力分布について）-（I）、日本趣筑学 会諭文報告焦 第131 号、pp.1-8、1967.1

10)日本コンクリート工学協会緆 : コンクリート便擥、p.66

11)H.Rusch、D.Jungwirth : コンクリート構造物のクリープと乾燥双 縮（百島祐信訳）、鹿島出版会、1976

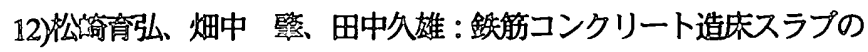
長期たかみに関する実鍳的研究（その1）、鹿島建設技術研究所年 瓡、第27号、pp.63-68、1979.6

13)岩原照次 : 両端固定銑筋コンクリート造一方向床スラプの長期曲 け゚徃状、コンクリート工学年次論文報告焦、Vol.9、No.2、pp.615620、1987.6

14)山本俊彦: 若材令時に過何重を受けたRCスラプの長期たわみ 真急建設汥術研究所坏、No.8、pp.85-92、1982

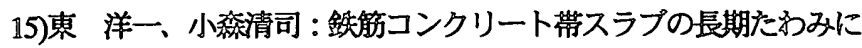

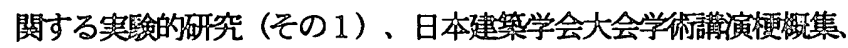

棈造系 II - II 、pp.1039-1040、1975.10

16)CEIB-FIIP Model Code for concrete structure. 1970

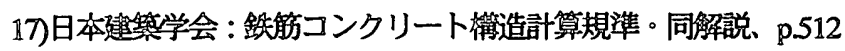

18)ACI Code 318-83

19)场 裕弘他 5 名: 高強度鉄筋を用いてプレストレスを導入した型 势兼用プレキャスト板に闑する実匼的研究（その4. 合成スラプの

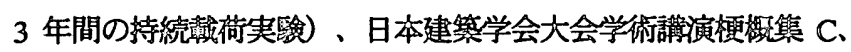
pp.1085-1086、1993.9

20)坂 静志、岡田 淯、六車 熙: プレストレストコンクリート、 朝倉書店、pp.403-408

21)日本建学会 : プレストレストコンクリート䛇計施工規㴰。同解 説. pp.114-115

22)伀筒育弘、星野克征 : 鉄筋コンクリート造底スラプの長期たかみ 量の定舅化に関する研究、日本建築学会関東支部報告集、pp.197200. 1982 